\title{
DE CURAÇAOSCHE BEGROOTING VOOR 1929
}

\section{II}

DOOR

\author{
MR. B. DE GAAY FORTMAN
}

Tot December van het vorige jaar heeft de minister de Tweede Kamer in het onzekere gelaten omtrent de vraag, of haar meewerking zou noodig zijn voor totstandkoming der Curaçaosche begrooting voor 1929. Weinig gesticht was men daarover, en de minister heeft gebruik gemaakt van de hem in den mond gegeven verontschuldiging, dat de gang van zaken voor hem nieuw was.

In tegenspraak met hetgeen ik verwachtte op grond van de bij de vorige begrooting in de Kamer door hen zoo vurig verdedigde autonomie van Curaçao hebben vele kamerleden zich terdege met de begrooting voor 1929, althans met verschillende belangrijke aangelegenheden, die gewoonlijk bij een begrootingsdebat plegen ter sprake te komen, beziggehouden. In de Tweede Kamer wel te verstaan; de Eerste heeft hierover geen mond opengedaan. De gehouden gedachtenwisseling noopt mij tot een vervolg van mijn in de laatste December-aflevering geleverde beschouwingen.

In de eerste plaats komt ter sprake de wijze, waarop de Kamer de Curaçaosche aangelegenheden in het debat wist te betrekken.

In het Voorloopig verslag op hoofdstuk XI der staatsbegrooting (departement van Koloniën) verklaarden "verscheidene" leden, zich het recht voor te behouden, om, als er geen Curaçaosche begrooting kwam, alsnog Curaçaosche vraagstukken ter sprake te brengen. „Sommige” leden brachten in hetzelfde stuk eenige onderwerpen ter 
sprake. En het waren weer ,verscheidene” leden, die om bij sluitende begrooting toch tot een behoorlijke jaarlijksche bespreking van de belangen van Curaçao in de Staten-Generaal te geraken, den minister in overweging gaven, in het regeeringsreglement voor dit geval een regeling te treffen als voor de Nederlandsch-Indische begrooting.

Met groote gulheid heeft daarop de minister op grond van zijn verantwoordelijkheid tegenover de Staten-Generaal voor het ten aanzien van Curaçao gevoerd beleid erkend, dat de sluitende begrooting in geen enkel opzicht inbreuk maakte op de vrijheid van gedachtenwisseling over aangelegenheden, dit gewest betreffende, tusschen volksvertegenwoordiging en regeering. Daaraan heeft de minister echter toegevoegd, dat de sfeer voor ruime toepassing van art. 61 der grondwet - zelfbestuur dus vooral moest worden .,behouden”. Dat „behouden” klinkt wat eigenaardig, als men denkt aan het verleden, aan de begrootingsrevisie op het Plein en de hanteering van art. $48 \mathrm{Rr}$., en aan het heden, dat maar niet opschiet met den eersten eisch der nieuwe grondwettelijke bepaling, de herziening der staatsinrichting dienovereenkomstig. Bij de mondelinge gedachtenwisseling in de Kamer is in denzelfden geest gesproken. o.a. door den heer Bijleveld, die zei, dat de minister, dezen bal kaatsende, dien kon terugverwachten, en door den heer IJzerman, die de mogelijkheid veronderstelde, dat de minister wel lichtelijk zou hebben gebloosd, toen hij het bovenstaande aan het adres der Kamer neerschreef, evenals de vos, die de passie preekt, en er bovendien op wees, dat de Koloniale raad, zooals deze thans wordt benoemd, moeilijk geacht kan worden te behooren tot de organen, aan welke de grondwet de regeling der inwendige aangelegenheden der overzeesche gebiedsdeelen wil overlaten. Het deed vreemd aan, dat de eerstgenoemde spreker ook in de toekomst de autonomie bestaanbaar achtte met handhaving van art. Rr., lijnrecht in strijd met het betoog der commissie-Staal, maar wellicht bedoelde hij meer, dat er een instantie boven het koloniaal bestuur moest zijn, dan wel 
dat deze de Kroon en niet de wetgevende macht diende te wezen.

Over de vraag, hoe het in de toekomst moest gaan, was men het niet eens. De heer Bijleveld vond het nog zoo kwaad niet, om bij „Koloniën” de belangen van Curaçao en het gevolgde beleid te bespreken, de heeren Joekes en Van Boetzelaer schenen te voelen voor de gedachte om denzelfden weg, als voor de Nederlandsch-Indische begrooting voorgeschreven is, te volgen, en althans de minister gaf aan een dergelijke behandeling de voorkeur.

Warm werd gepleit voor de bovenwindsche eilanden. Alle sprekers, de heeren IJzerman, Van Vuuren, Mrs. Joekes, Bijleveld en Van Boetzelaer namen het voor ze op. Of dat altijd even zaakkundig ging, is te betwijfelen. Zoo beweerde de heer IJzerman, dat St. Eustatius in de tweede helft der 18de eeuw 25.000 inwoners had gehad, en een half uur later verraste de heer Van Vuuren met de mededeeling dat de drie eilanden in hun besten tijd niet meer dan 5000 inwoners hadden.

De vrees, dat die eilanden het moeilijk zouden krijgen, nu de Staten-Generaal niet meer als superarbiter stonden over den Kolonialen raad, die zich er nooit veel van aangetrokken had, was in de memorie van antwoord bestreden met een beroep op de .... door dien raad den gouverneur in uitzicht gestelde medewerking bij de herinrichting van het belastingwezen, den voorgenomen belastingvrijdom, die echter moeilijk zonder zorg kan worden tegemoet gezien, als zij gepaard moet gaan met andere maatregelen, waarvan men ginds het ergste vreest. De heer Bijleveld zei, wat menigeen denkt: „Het schijnt toch waarlijk wel eenigszins alsof die eilanden min of meer geabandonneerd worden. Aan dien indruk kan men zich niet onttrekken."

Wie de voordracht van mejuffrouw Slothouwer in het Indisch Genootschap over de bovenwindsche eilanden onlangs bijgewoond heeft, zal begrijpen, dat ginds met ingenomenheid vernomen is, dat nagenoeg alle sprekers zonder uitzondering ervoor gepleit hebben, die eilanden meer onder de rechtstreeksche hoede van Nederland te bren- 
gen, en dat de minister uitdrukkelijk toegezegd heeft, deze zaak met den gouverneur te zullen bespreken. Wat zou men ginds gelukkig zijn met een Nederlandschen gezaghebber, een Nederlandschen rechter, een Nederlandschen dokter, een Nederlandsch schoolhoofd; men zou het staatkundig verband met Curaçao en den Nederlandschen landvoogd, te deelen met de benedenwindsche eilanden, wel op den koop toe willen nemen.

Het spreekt vanzelf, dat de heer Van Vuuren over de onderwijsgelijkstelling gesproken heeft. Wij begrepen daar uit, dat de minister dit kamerlid heeft toegezegd, ,,in drie etappen" de gelijkstelling te willen doorvoeren. De heer Van Boetzelaer van Dubbeldam juichte ook in die maatregelen, en vroeg, of een dergelijke gelijkstelling ook niet in de salarieering van predikanten en geestelijken kon worden bereikt.

Over de Caracas-baai spraken de heeren Joekes en Bijleveld. De minister betoogde, dat het woord in dezen is aan den Kolonialen raad, en hij, tot deze gesproken had, zijn oordeel opschortte. M̈en vraagt zich intusschen af, of dat college als een klein kind zijn tong verloren heeft, of wel Oost-Indisch doof geworden is.

Belangrijk waren de beschouwingen, die de heer Bijleveld hield over het financieel beleid, en over andere onderwerpen, reeds in onze vorige bespreking behandeld.

Summa summarum: de Kamer heeft zich geweerd. Het zou zonder twijfel levendig te betreuren zijn, als de pas gewekte belangstelling niet voldoende gaande gehouden werd door een jaarlijksche bespreking der Curaçaosche zaken in de Staten-Generaal.

Amsterdam, 29 April 1929. 